\title{
Authority and Dignity; History, Architecture, and Restoration of Sheikh Zahed Gilani Tomb
}

\author{
Maryam Pourzakarya ${ }^{1 *}$
}

\begin{abstract}
Tombs and mausoleums as a cultural-religious heritage have a key role in attracting cultural tourists, as a result, they have been of great interest to researchers and academics in recent years. This paper argues the tomb of Sheikh Zahed Gilani, who was once a great mystic and is reputable due to his influence on the formation of the Safavid dynasty. Through a qualitative evaluation, this paper assesses the history, indigenous architecture, brick decorations and the significant geometry of Sheikh Zahed' tomb. The results indicate that the dome has eight diverse geometric levels with dissimilar decorations, which is a unique design in the region. The paper also investigates the construction inscriptions and preservation projects to better comprehend the history of the tomb. Examination and understanding the characteristics of this monument alongside assessing the typology in comparison to other historical buildings can support the development of a local structure of the tomb as well as the geometric dome in similar climates.
\end{abstract}

Keywords: tomb, religious heritage, cultural heritage, Sheikh Zahed Gilani, indigenous architecture, dome

\section{Introduction}

The existence of sacred monuments has sometimes provoked the agglomeration of populations and urban formation. Despite Islamic prohibitions of constructing luxurious mausoleums, tombs are the most significant Islamic architectures after mosques and palaces as symbols of the power of the deceased leaders ${ }^{1}$. In the tombs and mausoleums, valuable examples of architectural, geometric and decorative techniques are attained that contribute to the sustainability of Iranian architecture. Additionally, shrines through functional and spiritual characteristics have a strong potential to develop into influential elements in an Islamic city ${ }^{2}$. A good example of these religious spaces is Sheikh Zahed Gilani's tomb which dates back to the early Safavid dynasty. The tomb is located on the slopes of a mountain and surrounded by tea farms in the Sheikhanebar village that is 2 kilometers away from Lahijan city in Gilan province, in Iran $^{3}$. Sheikh Zahed or Taj al-Din Ebrahim was a mystic, who was the master of Sheikh Safi al-Din Ardebili, the founder of the

\footnotetext{
${ }^{1}$ Master Graduate, School of Architecture, College of Fine Arts, University of Tehran, Tehran, Iran; Email: m.pourzakarya@ut.ac.ir (Corresponding Author) ORCiDs: https://orcid.org/0000-0003-0439-9584
} 
Safaviyya order, and had a great influence on the establishment of great Safavid dynasty ${ }^{4}$. The Sheikh Zahed tomb has a valuable architecture that despite some special features, to date, the history, indigenous architecture and typology of the monument have not been investigated in detail.

Lahijan, one of the oldest northern cities of Iran dating back to Sasanian Empire (224-651 $A D)^{5}$, is located 45 kilometers east of Gilan province's capital. The city was once the most important urban area and the largest one in the province as the capital of eastern Gilan ${ }^{6}$. In addition, based on the surveys, the number of mosques in northern Iran and the south of the Caspian Sea is more frequent than other parts of the country, because the Alevier's revolution ${ }^{7}$ encompassed a wide range of this region. This caused the settlement of many leaders and masters, and the construction of many shrines in these areas, especially in Lahijan, due to the establishment of karkiya dynasty ${ }^{8}$. Besides some of the shrines associated with the Imamzade ${ }^{9}$ and elders of religion, some tombs are also attributed to the soldiers and companions of the Imams ${ }^{10}$. With its historical-cultural history, Lahijan has many tourist attractions (Figure 1), the most significant of which are the National Tea Museum, the traditional pools and houses, historical mosques, and several shrines, comprising the Sheikh Zahed Gilani's tomb ${ }^{11}$. In the following, this paper will explore the architecture and structure as well as the decorations and inscriptions of the monument.

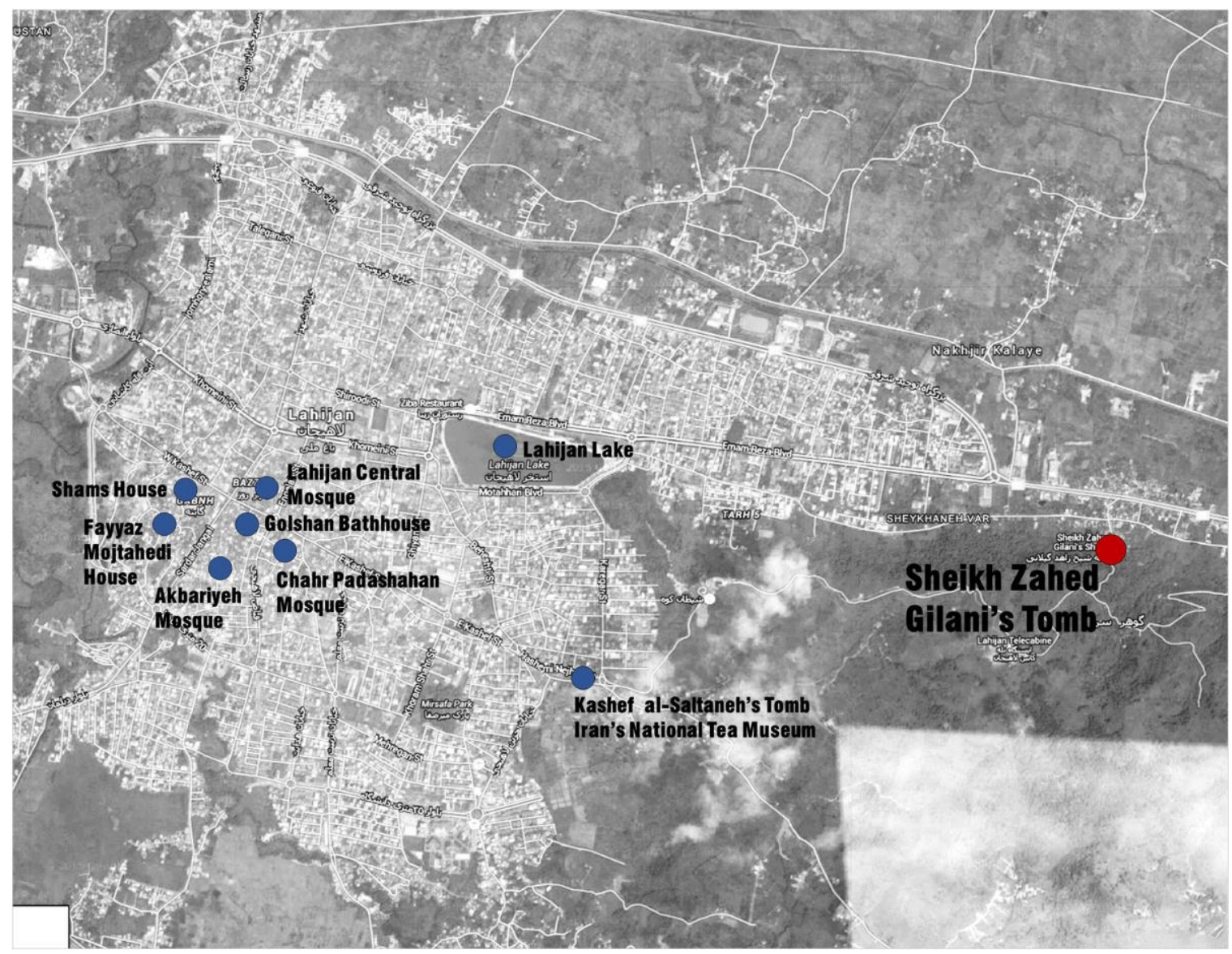

Figure 1. Lahijan City Map and the significant monuments. (author). 
Regarding the unique geometry and structure of the dome, the tomb requires strategic management and restoration plans. There are several questions such as, what is the architectural features of the tomb? What are the contradictions in the history and construction process? What is the significance of the dome in terms of design and geometry? how is the tomb compared to other constructed monuments in the region without any resemblance to its former ones? What are the impacts of renovation projects? To answer these questions, this paper tries to adopt an empirical research. Therefore, this study is based on case study research and qualitative method and data collection, which is used here to argue the historical conflicts in the construction of the Sheikh Zahed Gilani's tomb in Lahijan, Gilan, Iran, its significant features and the influences it can have on local religious monuments. In order to achieve the examination and documentation of current circumstances, the shrine was visited several times from October 2015 to February 2016 and architectural plans and elevations along with the dome's decorations were mapped by the author. Building on the interpretive-historical strategy, the secondary data was gathered from library studies, related publications and national organizations inclusing Iran National Cartographic Center, National Library of Iran and Gilan Cultural Heritage and Tourism Organization (GilanCHTO).

The paper also evaluates the dome's geometry and renovation projects that have been implemented so far to preserve the pyramid dome. Therefore, the study has been categorized into different sections. First, the introduction of Sheikh Zahed Gilani is presented. In the next section, architecture, dome's geometry and construction history will be evaluated. Before reaching the conclusions, typology comparison and restoration projects will be examined.

\section{Sheikh Zahed Gilani}

Taj al-Din Ebrahim Kurdi Sanjani, known as Sheikh Zahed Gilani, was a mystic of the $7^{\text {th }}$ and $8^{\text {th }}$ century $\mathrm{AH}\left(13^{\text {th }}\right.$ century) and in the sciences of Sophia, he was the leader of his contemporaries $^{12}$. Up to seven of Sheikh Zahed's ancestors were Sheikh and his seventh grandfather was Morid ibn Sheikh ${ }^{13}$. Sheikh Ebrahim Zahed Gilani was born in 615 AH (1218) in Siavaroud, Gilan, and died in $700 \mathrm{AH}(1301)$ at the age of $85^{14}$. He was an apprentice of Jamaluddin Gilani since his childhood, and the series of his mysticism is related to Jenid and from him to Imam Ali ibn Abi Talib (AS). Jamaluddin Gilani attributed the title 'Zahed', meaning ascetic, to Sheikh Zahed, as a result of his moral characteristics such as asceticism, contentment, and courtesy ${ }^{15}$. After tolerating many austerities, Sheikh Zahed received the position of Leader from his master. However, he did not begin his job as a leader until twenty years after his master's death through spiritual cultivation and authority ${ }^{16}$.

Sheikh Zahed had two wives and four children; his first wife was the daughter of his master, Jamal al-Din, and his second wife was the daughter of his servant, Akhi Soleiman; from whom he had a girl named Bibi Fatima, who got married to Sheikh Safi al-Din Ardebili ${ }^{17}$. Political intelligence of Sheikh Safi al-Din Ardebili was encouraged by Sheikh Zahed Gilani (Figure 2). Subsequently in addition to mystical practices, Sheikh Safi al-Din learned the strategies for developing his own discipline. These approaches were converted to a political movement towards Safavid credo and he eventually became the founder of one of the great dynasties in Iranian history called the 'Safavid Dynasty ${ }^{18}$ ' (1501-1736) ${ }^{19}$. 

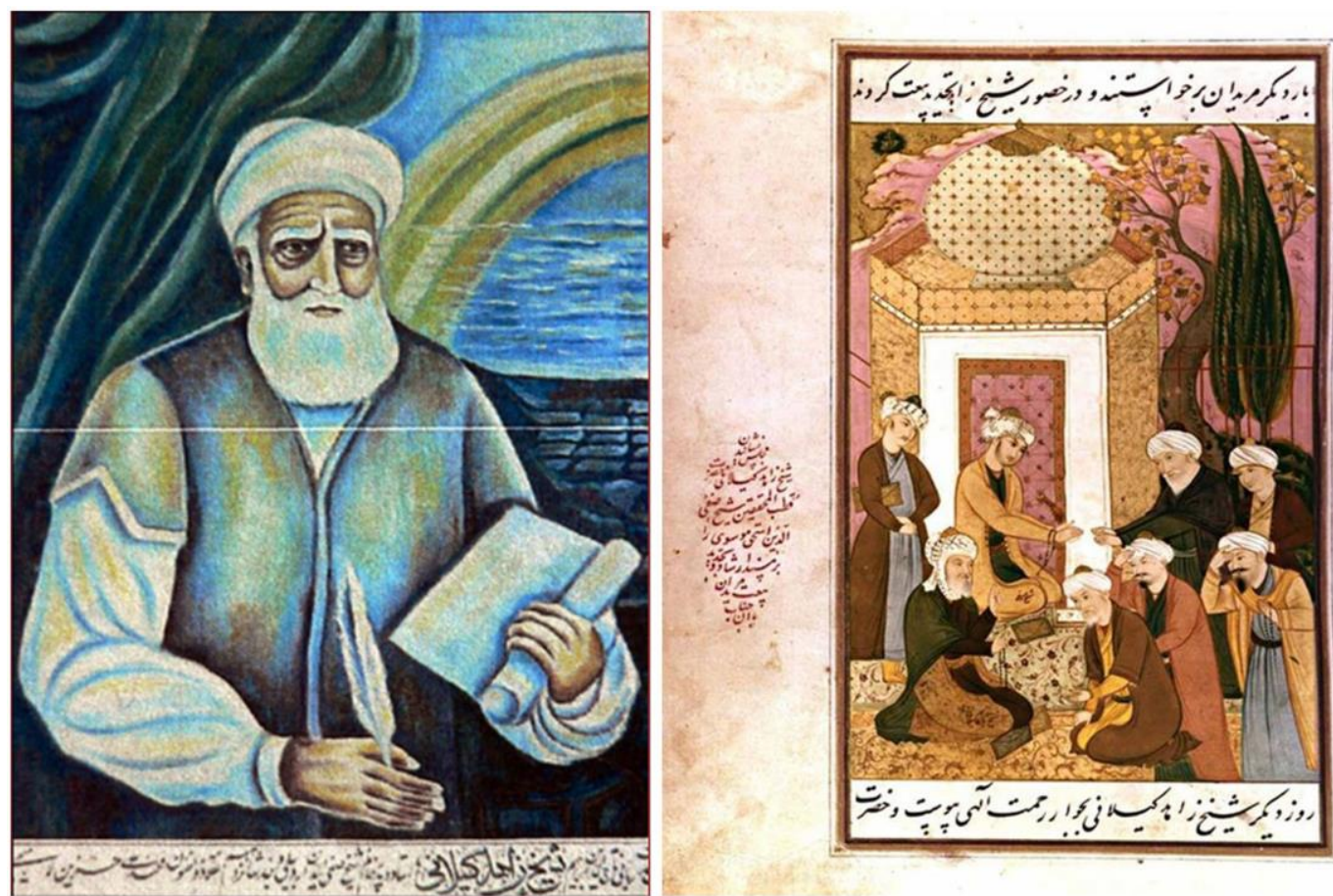

Figure 2. Pictures of Sheikh Zahed Gilani, determining his son-in-law and the title of Safavid dynasty, Sheikh Safi al-Din, as his religious and spiritual successor. (author).

Regardless of his opponents' efforts after the death of Sheikh Zahed, they could not prevent Sheikh Safi's succession. Sheikh Safi was the true representative and successor of Zahediyeh order in Gilan and all places where Zahediyeh's followers were present at the end of Sheikh Zahed's life. Zahediyeh order was founded by Sheikh Zahed as a precursor to the Safavid credo which had a huge influence on the history of Iran. To close, Sheikh Zahed became ill in the district of Surmere and was transferred to Siavaroud rural area by his disciple, Sheikh Safi al-Din. He died after 14 days in $700 \mathrm{AH}$ (1301) and was buried in Siavaroud ${ }^{20}$.

\section{Monumental architecture}

Sheikh Zahed Gilani's tomb, dating back to the late Timurid Empire ${ }^{21}$ and early Safavid dynasty, is located on a hillside in Lahijan, where seems to be the place of austerity of the Sheikh $^{22}$ (Figure 3). The climatic and natural features of the Gilan's foothills region have affected the tomb's structure. The monument is situated in a traditional indigenous district surrounded by residential buildings and green spaces. Access to the building is achieved through steps mounted on the hillside, and, green spaces, trees, and water streams have been considered on both sides ${ }^{23}$. 


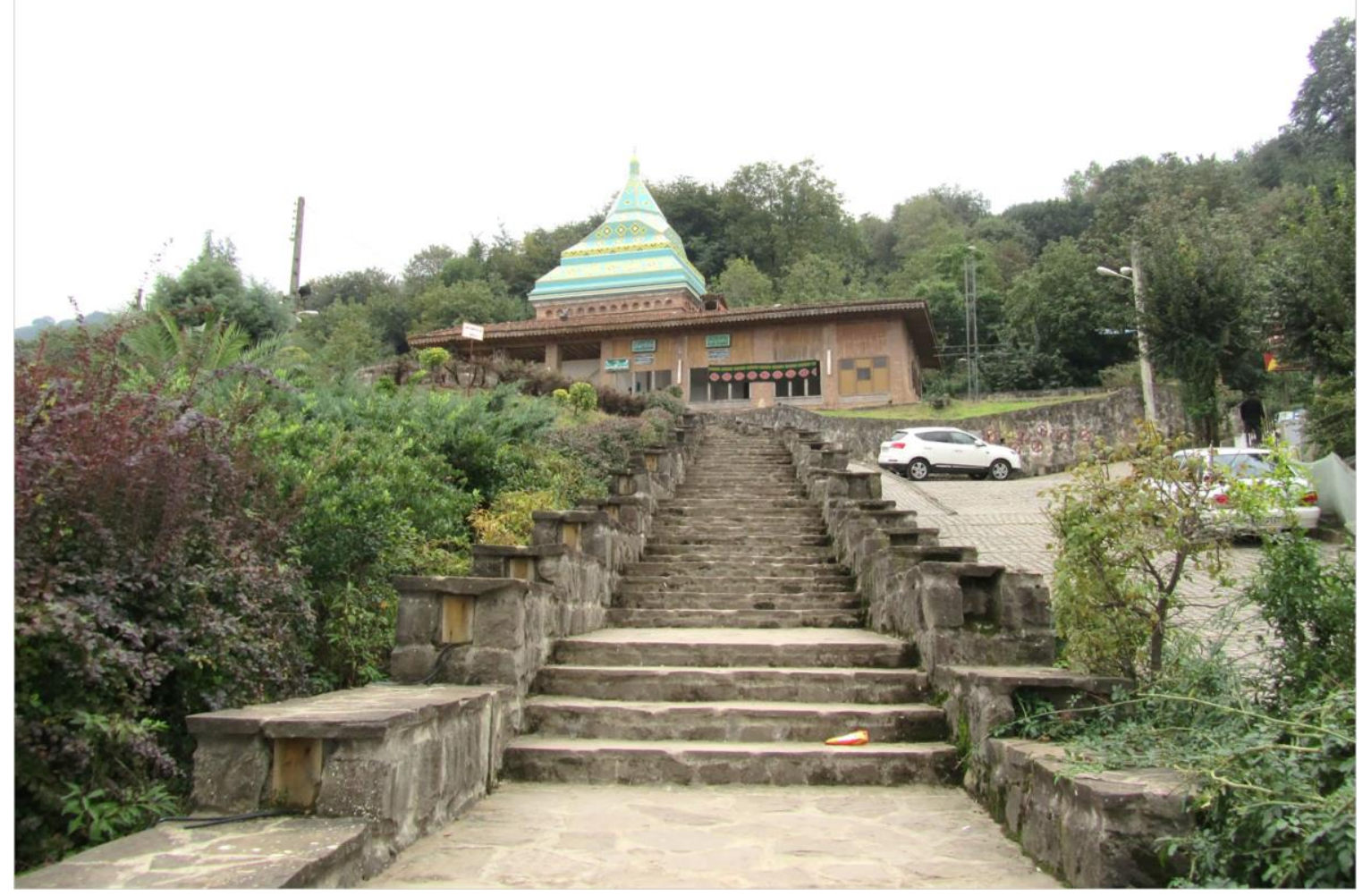

Figure 3. Tomb from northern view and also the main stairs to the monument. (author).

The Sheikh Zahed Gilani's tomb, physically, consists of two rooms, one square-shaped and another rectangular and has porches or Iwans, a rectangular hall/space, usually roofed, with walls on maximum three directions in three sides. The porches have a significant and symbolic value that facilitate spatial communication. Due to the stagnant, relatively humid and heavy indoor air, these porches along with the open frames to the courtyard provide air displacement ${ }^{24}$. Similar to most buildings in Gilan, the porches are considered in southern $(8.25 \mathrm{~m}$ long $* 2.40 \mathrm{~m}$ wide), eastern $(8.90 \mathrm{~m}$ long $* 2.80 \mathrm{~m}$ wide) and northern $(20 \mathrm{~m}$ long * $2.86 \mathrm{~m}$ wide) directions of the tomb $\mathrm{m}^{25}$. Moreover, due to the humid air and low depth of the groundwater, the building has no basement ${ }^{26}$ and the first floor has been constructed above the ground level so that the indoor spaces can be protected from moisture and humidity and can be benefited from winds with higher speed at higher altitudes ${ }^{27}$. The materials used in the religious buildings of this region are sustainable materials that are as well resistant to moisture and rain. Therefore, the physical structure of the tomb is constructed from lightweight materials such as wood or brick and calcareous mortar and for roofing, wooden trusses are built below the pottery or Aleppo sheets, organization of which is on skeins of columns $^{28}$. Furthermore, the sloping roofs, often found in the Caspian Sea coast architecture, continue on top of the porches to provide shade spaces for users and to reduce the rain effects ${ }^{29}$.

The entrance door to the tomb, is on its eastern side. First, we enter the domed chamber, where a zarih of a person called Seyed Razi is situated. A zarih is a wooden lattice structure, which surrounds a grave in an Islamic mausoleum or shrine. From the western side, we can 
enter the long room, in which is the sepulcher of Sheikh Zahed (Figure 4). This room is $11^{*} 4.3 \mathrm{~m}^{2}$ and the floor and the walls are tiled up to $143 \mathrm{~cm}^{30}$. Based on the formation hierarchy of the building, it seems that the domed chamber was built prior to construction of the room of Sheikh Zahed Gilani's tomb and the assembly of the dome. Attributable to the thickness of the walls and the type of ceiling used in rooms 1 and 2, it seems that room 1 was first constructed and subsequently, room 2 together with porches were built as an addition to the tomb (Figure 4 and 5). There is no evidence to indicate the exact construction date of the building. As stated by library sources, it is known that the principle of sepulcher was constructed in $700 \mathrm{AH}$ (1301) by the death of Sheikh Zahed; then around $730 \mathrm{AH}$ (1329), the tomb was renovated by Safi al-Din Ardebili. After 192 years, in $892 \mathrm{AH}$ (1487), Sultan Heydar relocated the tomb on the orders of Sheikh to the Sheikhanebar rural area near the city of Lahijan. It also had inscriptions which were lost in the fire in 1282 or $1292 \mathrm{AH}^{31}$ (1865 or 1875). In a distance of two meters from the wooden zarih, there is a tiled grave, belonging to the daughter of Tamerlane ${ }^{32}$, above which is a cradle (Figure 5). The grave is $120 \mathrm{~cm}$ from above the cradle to the floor, has a length of $210 \mathrm{~cm}$, and is decorated with painted traditional tiles ${ }^{33}$.

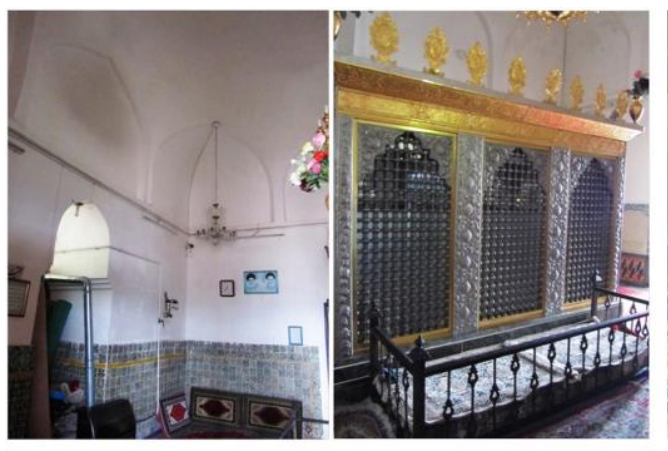

Room Nol

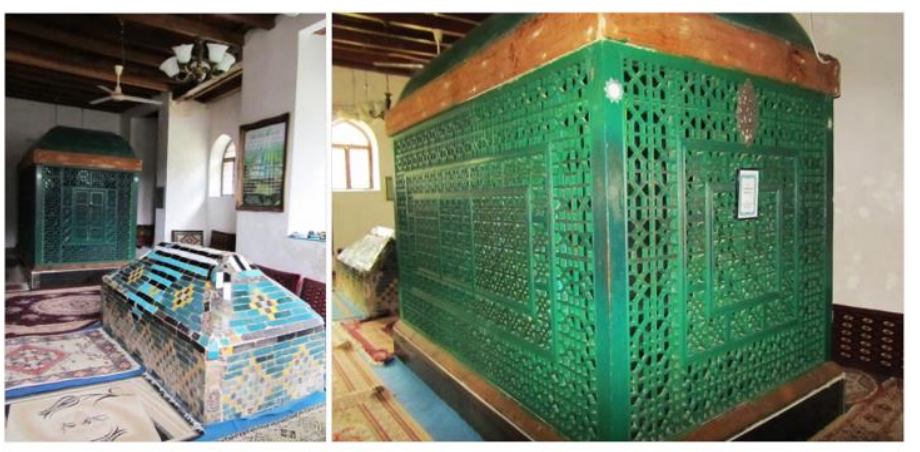

Room No2

Figure 4. Room 1, zarih of Seyed Razi; Room 2, sepulcher of Sheikh Zahed and the grave of Tamerlane's daughter. (author).
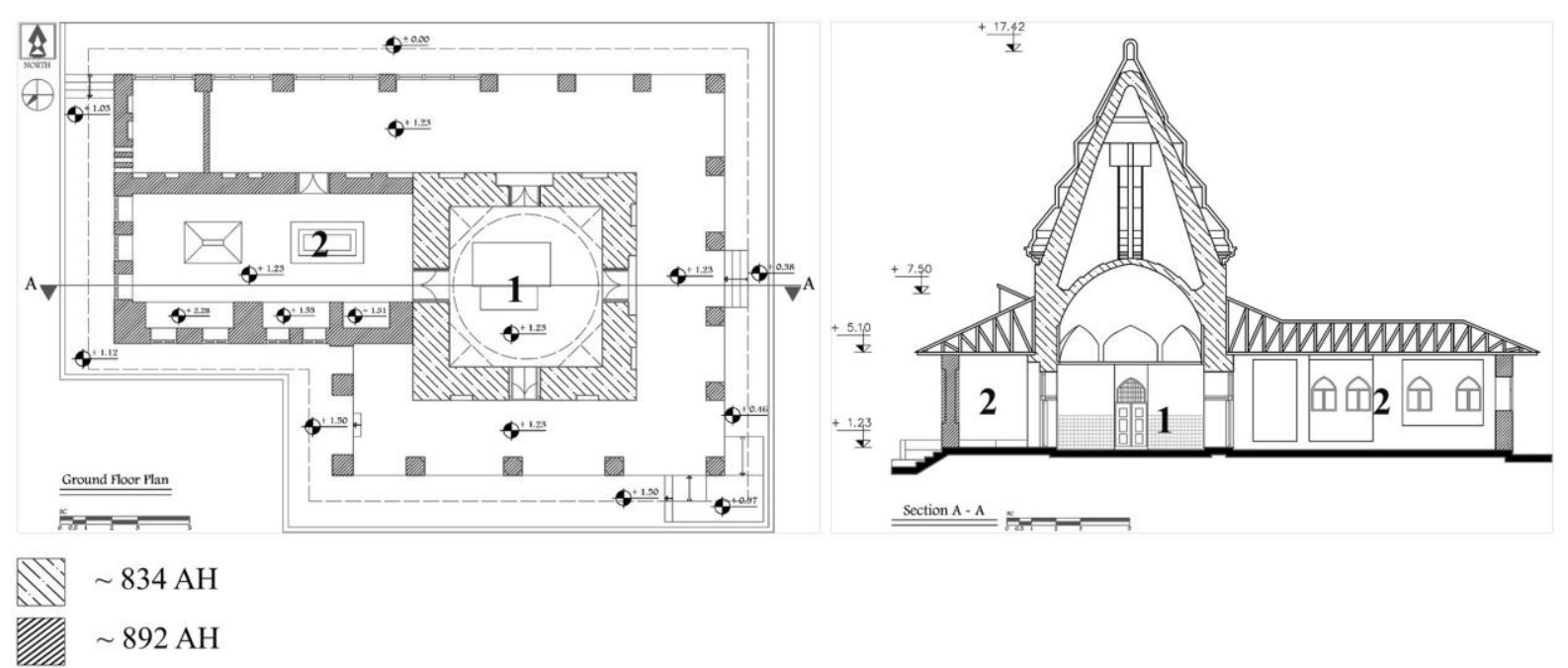

Figure 5. Hierarchy of construction in Sheikh Zahed's tomb. (author). 


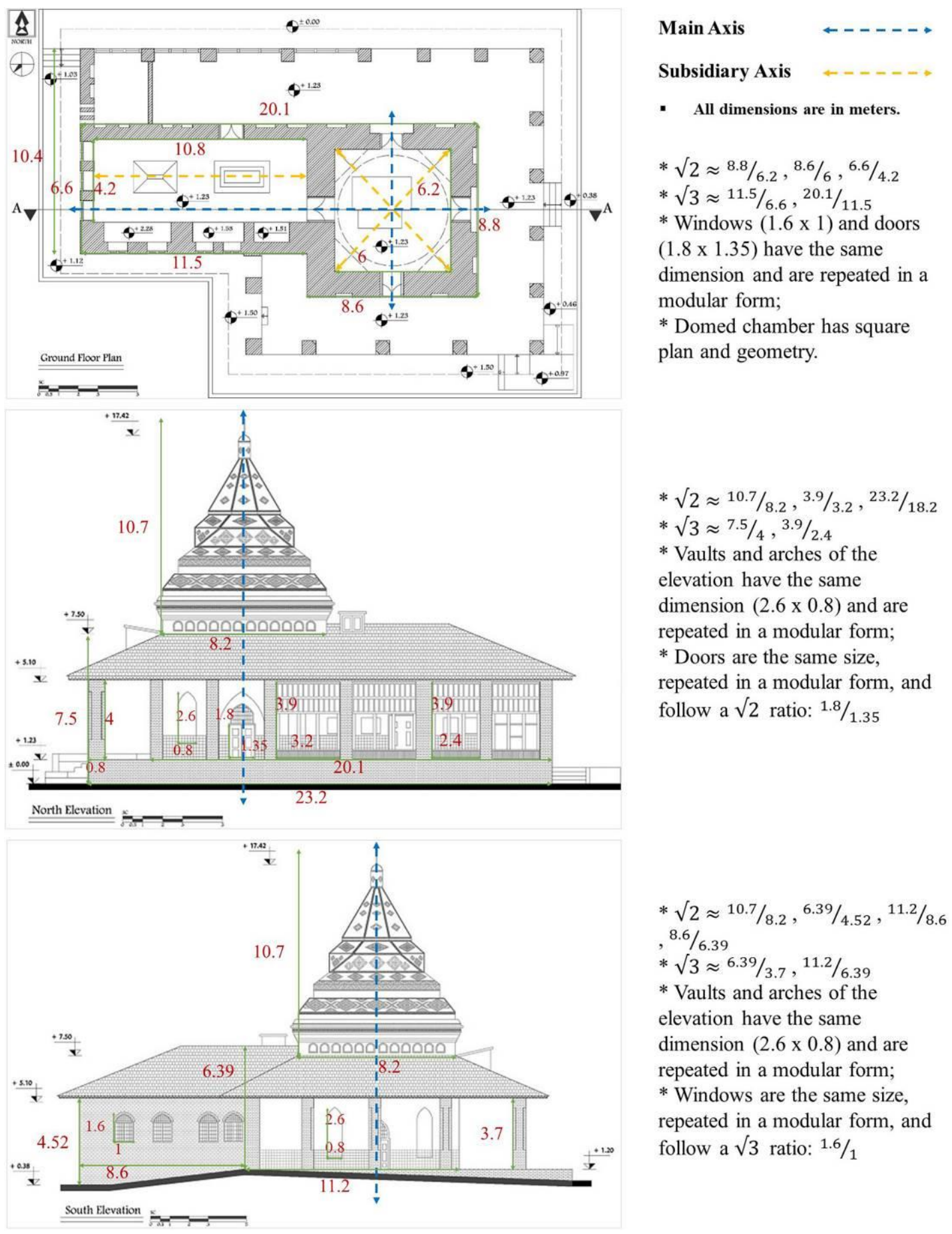

Figure 6. Examples of golden ratios in tomb's architectural plan and elevations. (author).

As it is exhibited in the plan and section of the domed chamber and other parts, the golden ratio ( 1.61803) is used in the tomb's architecture (Figure 6). Domed chamber has a square geometrical plan and the walls dimension inside and outside the room follow the golden ratio ( $\sqrt{2}$ ). The humanitarian approaches are to observe the human scale in the doorways and shelves, and to harmonize the dimensions of openings and lighting with space, which are used in the tomb's structure. In addition, the proportions of this monument are completely compatible with the tomb's function and indigenous culture. All windows are the same size $\left(1.6 \mathrm{~m}^{*} 1 \mathrm{~m}\right)$ as well as the doors $\left(1.8 \mathrm{~m}^{*} 1.35 \mathrm{~m}\right)$ and they are repeated in a 
modular form ( $\sqrt{ } 2)$. This recurrent practice can also be found in other parts of the structure. Vaults and arches of the elevations have the same dimension $\left(2.6 \mathrm{~m}^{*} 0.8 \mathrm{~m}\right)$ and integrated shape. Other width, length and height of the building walls in all four sides alongside the columns, porches and the dome follow the golden ratio modules ( 22 or $\sqrt{ } 3$ ), displayed in Figure 6. Other features of the building are the implementation of strengthening's principles, which can be realized from building's resistant to several earthquakes since its construction $^{34}$.

\subsection{Dome geometry and decorations}

he most significant part of Sheikh Zahed Gilani tomb is the dome structure. The tomb is a pyramid-shaped monument with clay roof-covering and a kind of the Rok Dome ${ }^{35}$, or pointed dome ${ }^{36}$ that is covered with stucco from the inside ${ }^{37}$. A pyramidal or conical dome that was often placed on a cylindrical or prismatic and was usually used for the shrines of sultans $^{38}$. The pyramidal dome is the most extraordinary part of the tomb since it is dissimilar to other pyramidal domes in Iranian indigenous architecture ${ }^{39}$. The bottom of the dome is square-shaped, that develops into an octagonal pyramid at the top. This conversion is a symbol of the mausoleum of Sufi spiritual masters ${ }^{40}$. Sheikh Zahed's dome relies on detailed and complex geometric drawings. Perhaps, architects of the time discovered that the only way to preserve the dome is to build it in the form of a pyramid so that rainwater could quickly pass and does not leave any moisture ${ }^{41}$. Therefore, the pyramidal dome of Sheikh Zahed's tomb can be considered as a suitable model for designing a dome in this verdurous and rainy region since the dome's designer, by planning a grid of 45 and 63/43 degree intersecting lines as a geometric basis for scheme, has achieved a design that has a great harmony with the region's indigenous culture, architecture, identity and climate ${ }^{42}$.

The geometry of the high dome with two discrete shells ${ }^{43}$, which is covered with blue and yellow tiles in exterior and is grounded on four half-cones arches in the interior, is partitioned into eight levels (Figure 7). These structures are used for converting square to the octagon for dome execution. The levels are designed with small triangle- and rhombusshaped tiles, transfiguring from the pyramidal quadrangles into octagonal sides. The circular warhead is located on the tip of the dome and has five yellow decorative rhombuses. In the old images of the building, there was a metal object above this warhead that does not exist at the moment and has been removed or abducted at the restoration process ${ }^{44}$. Tiling was probably replaced during the Qajar period (1790-1925) ${ }^{45}$ and has been renovated several times since and the application of yellow tiles was popular in Qajar architecture ${ }^{46}$. Due to the old photographs (Figure 7), the arches at the first level were covered with simple blue tiles, which today, there is no trace of it, and the stucco beneath the tiles has also been removed causing the emergence of the brick appearance.

Decorative arts in religious architecture provide a sign of discovery and intuition, giving the viewer spiritual peace alongside the vibrant colors and shapes. One of the fine arts in Iranian architecture is tiling that is in fact a replacement for wall painting and has been used to decorate and solidify the building. With the advancement of tile works in Iran, the artists with combining diverse colors created different techniques of tiling and with the mixture of 
brick and plaster were able to invent a reasonable tile; so that from the $5^{\text {th }}$ century $A H\left(11^{\text {th }}\right.$ century), fewer monuments were built without tile decorations ${ }^{47}$.

The major and most important physical decorative element of the tomb is the tile decoration ${ }^{48}$. On the southwest and northwest sides of the domed chamber, on the plinth of the walls, tiles by the haft rang ${ }^{49}$ or seven-colored technique with the floral pattern, are exhibited, belonging to the Qajar period ${ }^{50}$. The tiles of the dome and the grave of Tamerlane's daughter is of moagheli51 or brick-tiling technique ${ }^{52}$. In general, the designs used in tiling are in the form of rhombuses and glazed tilework which were widespread in the Timurid (1370-1507) and Safavid (1501-1736) dynasties. From other decorations is a set of brick ghatar-bandies or stringcourses on the first level of the dome, playing both the decorative and structural role. Ghatar-bandi is the work of decorations as a strip in a straight line. Beside tile and brickwork in the west elevation (Figure 8), wood carvings and decorations as Girih tiles that are a group of five tiles, applied in the production of Islamic geometric patterns using strap-work for decoration. These decorations are also found in the Zarih of Sheikh Zahed, wooden reticular windows and edges of the roof ${ }^{53}$.
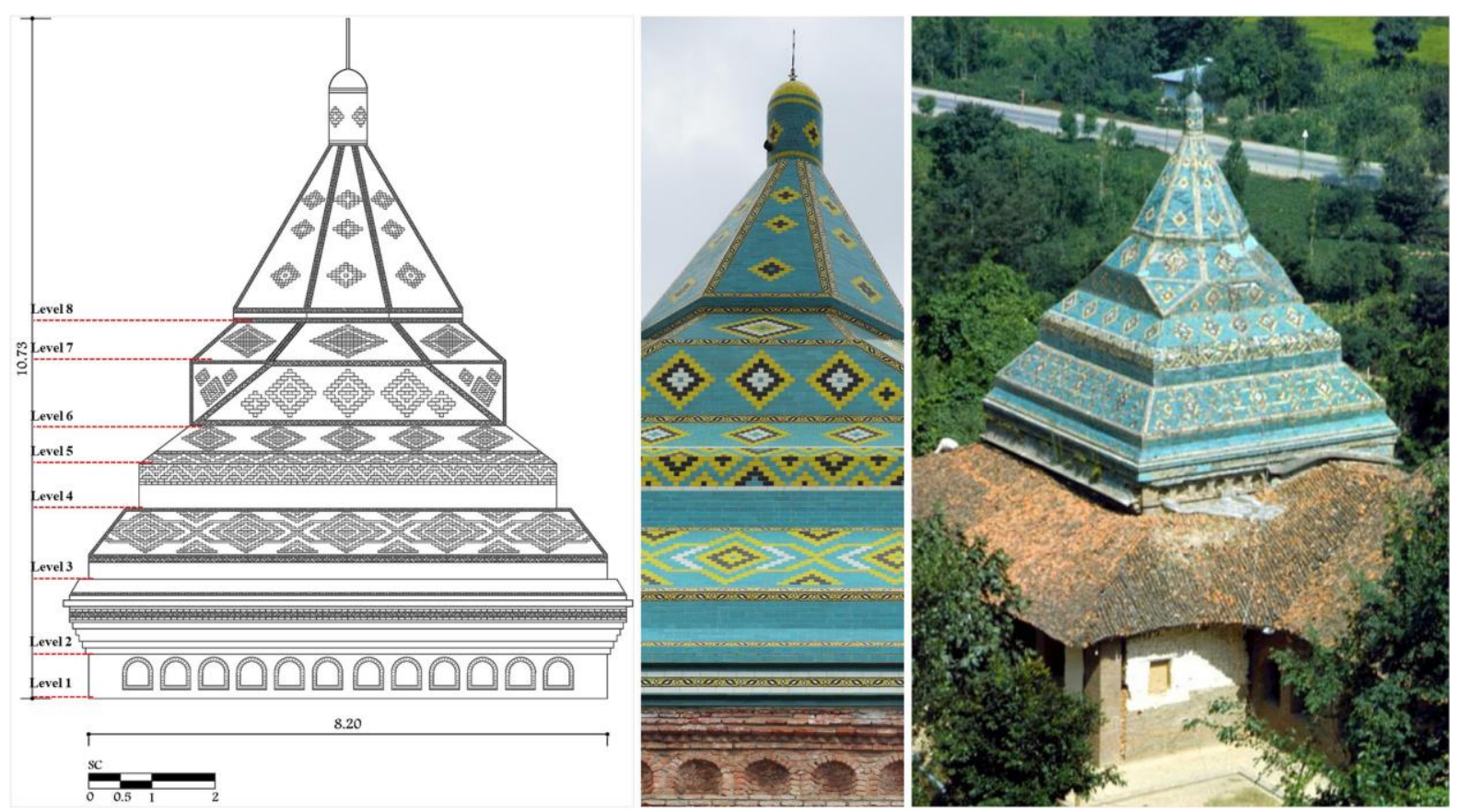

Figure 7. Images and pattern details of the dome's tile decorations of Sheikh Zahed's tomb. (author). 


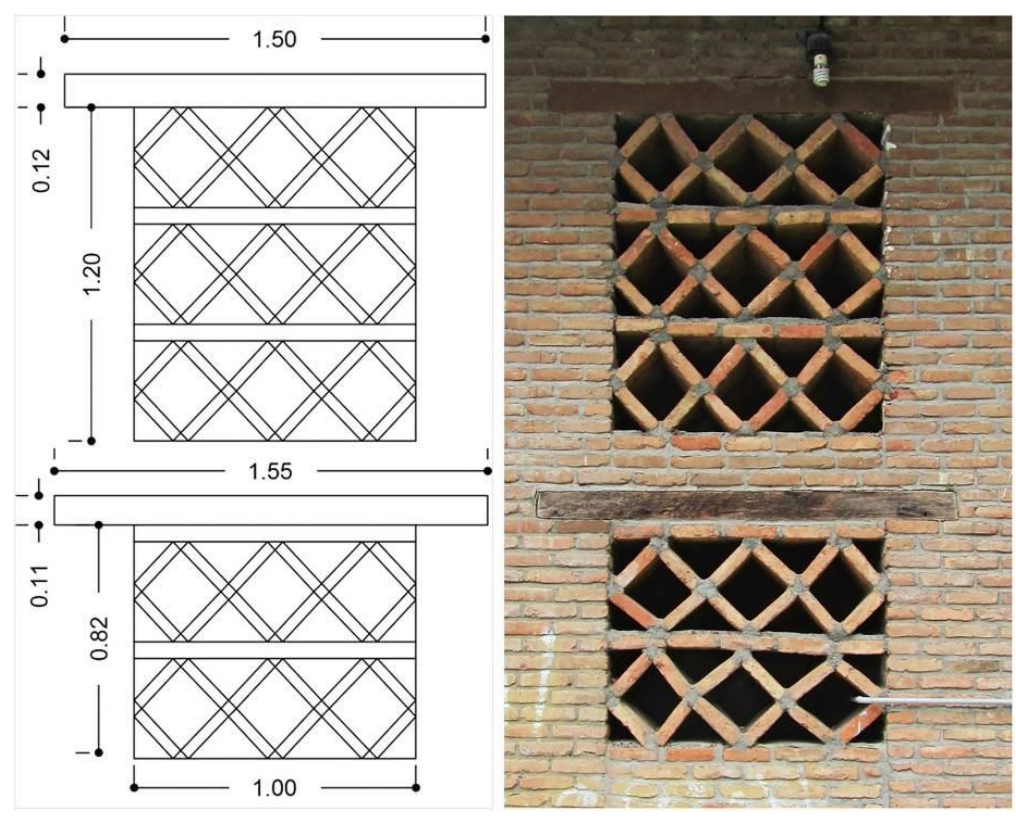

Figure 8. Brick decorations using strap-works (Girih tiles) in the west elevation. (author).

\subsection{Construction history and inscriptions}

In the monument, there is no inscription of the founder or the sponsor of the tomb. However, it is assumed that the tomb's constructor was someone named Seyed Mehdi Bashkajani. The only inscription in the building is an inscription with bad handwriting on the old wooden sepulcher of Sheikh Zahed's tomb, depicting the date of $822 \mathrm{AH}$ (1419). According to the tomb's architectural characteristics, it can be verified that the work belongs to the $8^{\text {th }}$ or $9^{\text {th }}$ century $\mathrm{AH}^{54}\left(14^{\text {th }}\right.$ and $19^{\text {th }}$ century). This wooden sepulcher was illustrated and carved, which Rabino (1995) and Nafisi (1928) believed to have disappeared in one of the fires before their time, e.g. $1331 \mathrm{AH}^{55}$ (1913).

It is deduced from the inscription of the sepulcher that the body of Sheikh Zahed, who died on Tuesday 24 Rabi al-Thani 700 AH (14 January 1301), is buried here and carpentry's decoration belongs to the work of Abdullah Doroudgar ${ }^{56}$. The inscription of Sheikh Zahed' tomb is as follows (Figure 9):

'Everything has a face - judging by him and returning to him - here is the sepulcher of the seeker of mysticism and austerity, a mystic and a pious, Sheikh Zahed, who passed away on the afternoon of Tuesday, 24 of Rabi 'al-Thani in $700 \mathrm{AH}$ - the work of Abdullah Doroudgar'

And the inscription on the entrance door (Figure 9):

'this door is to the affair of Seyed Razi ibn Mehdi Hosseini Bashkajani in $822 \mathrm{AH}$ and the carpenter is Ahmad Yadegar' 


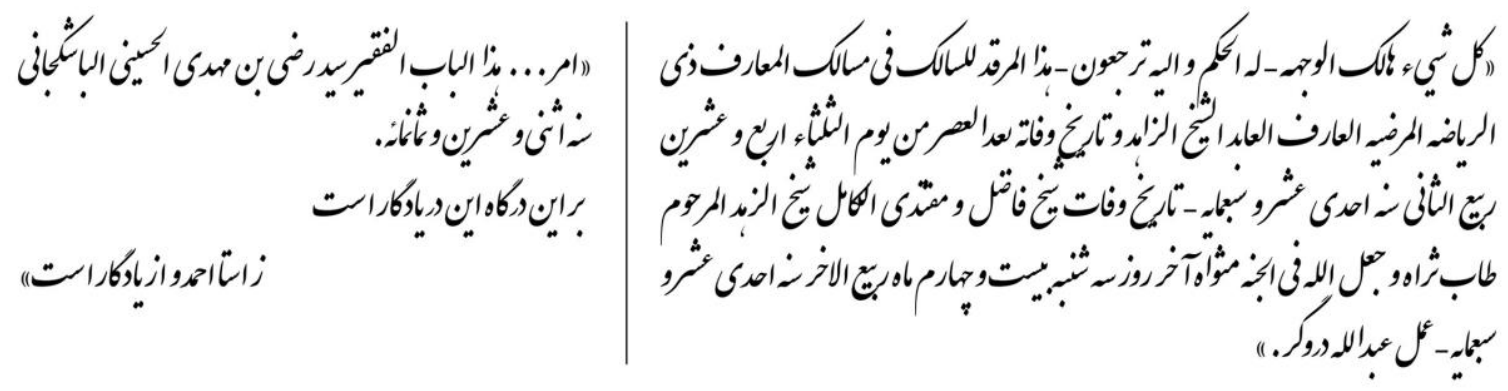

Figure 9. Inscriptions left: on the entrance door, right: on the sepulcher of Sheikh Zahed. (author).

These contradictory contents demonstrate that historians were careless in writing historical materials. If Sheikh Zahed died on Tuesday 24th Rabi al-Thani in $700 \mathrm{AH}$ (1301) and was buried there, then how is it possible that he was first brought to Siavaroud on the orders of Sheikh Safi al-Din Ardebili, and he died there after 14 days, and subsequently in $892 \mathrm{AH}$ (1487), Sultan Heydar, transformed the body to this current location? Moreover, a sepulcher is under the pyramidal dome that should be the tomb of Sheikh Zahed since the significant dome and monument must have been constructed for a great man like him; however, on the grave below the dome, is a Zarih which indicates that there is the grave of Seyed Razi ibn Mehdi al-Hosseini al-Bashkajani who passed away in $834 \mathrm{AH}^{57}$ (1430). Seyed Razi was the son of Seyed Ali Kia, who was one of the rulers of Lahijan and died in $829 \mathrm{AH}$ (1426). What is more, in line with Rabino (1995) and Nafisi (1928), if the sepulcher of Sheikh Zahed and the entrance door, which was donated by Seyed Razi ibn Mehdi Hosseini Bashkajani, was destroyed in the fires of 1282 or $1292 \mathrm{AH}$ (1865 or 1875), then why the sepulcher of Sayed Razi, who died in $834 \mathrm{AH}$ (1430), has hitherto remained in this chamber? It is probable that the sepulcher and the entrance door, which had historical and artistic qualities, might have gotten stolen similar to other valued sepulchers.

\section{Typology in comparison with other historical monasteries}

Due to the attention and respect of Muslims, the religious mausoleums, often referred to as the Imamzadeh, have been developed as highly magnificent complexes over the past decades. Tombs are often built with circular, square, and octagonal plans with various architectural styles. Similar to other Islamic buildings, tombs are decorated with colorful brick, plaster, tile and glasses. Such buildings in the period of Islam Iran had a special significance and are also known as towers, domes, mausoleums and sepulchers ${ }^{58}$.

Guilan tombs are among the buildings that, despite a relatively similar pattern to the architecture of the central plateau of Iran, have a different structure in form. This physical difference reflects the interdependence of climate and culture. The five tombs of historical value in Lahijan are: (1) Mir Shahid, (2) Mir Shams Al-Din, (3) Chahar Padashahan, (4) Seyed Razi and (5) Sheikh Zahed Gilani (Table 1). According to existing documents (including historical books, travelogues, and inscriptions), these tombs were built between the eighth and thirteenth centuries $\mathrm{AH}$ and various parts have been added to or removed from the buildings over the years ${ }^{59}$. The main significance is the establishment of the tomb that provides morphological research. It is tried here to reach the architectural types of the tombs in eastern Gilan, Lahijan. 
- Foundation: As a result of the high groundwater level and the need for a ground floor on a higher level, these buildings also follow the dominant architectural pattern of the region ${ }^{60}$. This kind of foundations act as a platform with a number of steps to access the building. This distance between the building and the ground prevents any moisture from spreading to the first floor ${ }^{61}$. All tombs have a foundation with 50 to $120 \mathrm{~cm}$ height, no higher than a standard floor.

- Walls: The walls are all porters. The architect chose brick wall construction, which was one of the building materials of prominent communities, to ensure the durability of the building and to double its significance.

- Porch: Roofed porches, which sometimes cover a large area, play an important role in the use of semi-open spaces, especially during rainy season ${ }^{62}$. All the evaluated buildings have a porch whose number and shape vary from one porch to four porches, following the dominant forms in Gilan architecture.

- Burial room: In all cases, buried rooms follow the geometric shapes. Half of them are rectangular and often square (square-based octagonal or square-based cross). The best orientation for having the right light is the north-south direction in accordance with the regional climate. Examination of the buildings reveals that most of them follow this positioning and accordingly climatic conditions have a major influence on the architecture of the buildings ${ }^{63}$. Accessibility varies from one door to four. This communication provides easy access for pilgrims to the shrine. In the cases examined, none of the sepulchers had a particular orientation towards Qibla.

- Columns: The shape of the columns in the facade is of three types of brick-based decorations, simple wood or a combination of the two. The first type is more favored since it allows for greater load-bearing and consequently larger spans.

- Roof: The roof of a building often consists of two upper and lower parts. The upper part was covered with red clay tiles before the arrival of materials such as Aleppo from Russia, and used to be called clay-roofing in the area ${ }^{64}$. Pottery entered the region from the Soviet Union and northwest of Gilan during the late Qajar dynasty and is now the location of the majority of pottery workshops and buildings ${ }^{65}$. Gilani's architect did not have access to arch technology as elsewhere in Iran; hence, the application of sloping multi-stacked roof alongside the rectangular wooden structure provides a barrier to rainwater reaching the walls.

- Decorations: Due to the prevalence of wooden materials in Gilan architecture and the lack of flexibility (compared to clay), the decorations mostly include woodcarving in the windows, pulpits or sepulchers. 
Table 1. Characteristics of the physical elements of the designated tombs. Author.

\begin{tabular}{|c|c|c|}
\hline Monument & Architectural Plan & Characteristics (Burial Room) \\
\hline Mir Shahid & $\therefore$ & $\begin{array}{l}\text { Entrance: east } \\
\text { Form: square } \\
\text { Column: simple wood } \\
\text { Roof: three-stacked, four-slope } \\
\text { Number of porches: four }\end{array}$ \\
\hline Mir Shams Al-Din & & $\begin{array}{l}\text { Entrance: east } \\
\text { Form: square-based octagonal } \\
\text { Column: combination } \\
\text { Roof: three-stacked, four-slope } \\
\text { Number of porches: four }\end{array}$ \\
\hline Chahar Padashahan & & $\begin{array}{l}\text { Entrance: north } \\
\text { Form: square-based cross, } \\
\text { rectangular } \\
\text { Column: brick-based decorations } \\
\text { Roof: three-stacked, four-slope } \\
\text { Number of porches: one }\end{array}$ \\
\hline Seyed Razi & & $\begin{array}{l}\text { Entrance: east } \\
\text { Form: square-based octagonal } \\
\text { Column: brick-based decorations } \\
\text { Roof: three-stacked, four-slope } \\
\text { Number of porches: two }\end{array}$ \\
\hline Sheikh Zahed Gilani & & $\begin{array}{l}\text { Entrance: east } \\
\text { Form: square } \\
\text { Column: brick-based decorations } \\
\text { Roof: two-stacked, four-slope } \\
\text { Number of porches: three }\end{array}$ \\
\hline
\end{tabular}

Given the similarities in the structure and function of the tombs of Sufis and mystics in different climates and over many centuries, the attention of historians has been brought to the common points of their thinking. From the start, the Bayazid Bastami tomb in Bastam and the tomb of Sheikh Zahed Gilani in Lahijan show similarities from the outside. Bayazid Bastami was a Persian Sufi and ascetic from north-central Iran who lived from 804 to 874 and was buried in the known tomb in Bastam. The pyramid-shaped dome of these two monuments is the first key to connect the two that drives the mind from the symmetry of architecture to the continuity of intellectual flows. Although the tomb of Sheikh Zahed is located in a humid and rainy region and in a completely different climate from four-season weather of Bastam, they are still alike in architectural form and structure. The turquoise 
color of the dome of Bayazid Bastami tomb has been transformed into various colors with a turquoise background in the dome of Sheikh Zahed Gilani tomb. Furthermore, the pyramid shape of the dome of Bayazid complex becomes a greater multi-level pyramid in the dome of Sheikh Zahed tomb (Figure 10).
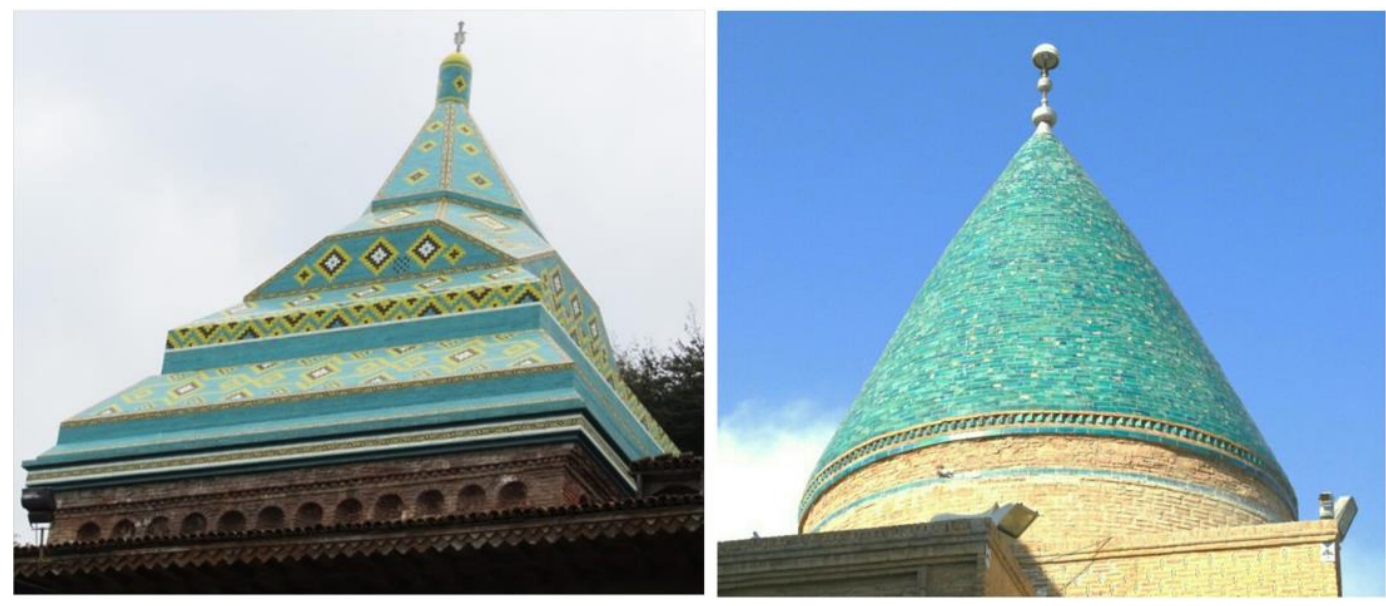

Figure 10. Dome structure of: left: Sheikh Zahed tomb; right: Bayazid tomb. (author).

What drives the mind from Bayazid to Sheikh Zahed, apart from Sufism, was the placement of two graves with two Sunni and Shia Islam intellectual flows in one space. In both monuments, there is a sepulcher of a prominent person with a different sect in the next room. This indicates that different intellectual flows have used each other's religious power, which at times has angered the powers of their time. Nonetheless, the architectural capacities facilitated the intellectual currents to reflect their peaceful coexistence in Iran's medieval history along with the challenges and disagreements ${ }^{66}$.

\section{Conservation and preservation of the tomb}

Sheikh Zahed's tomb was registered on National Heritage List in 1967 with the number of 646 and has been strengthened and restored several times by GilanCHTO ${ }^{67}$. The available reports from the National Library of Iran demonstrate that the first restoration project of the tomb was implemented in 1958 by Iran National Organization of Archeological Heritage's Protection. In this project, a metal scaffold was installed in order to map and repair the dome and to restore its tiles. The windows and wooden doors were also replaced $^{68}$. In 1980 and 1981, numerous repairs were executed comprising replacement of the ceiling plaster of the domed chamber, renovation of porches' wooden ceiling, repair of the floors' and plinths' tiles, tiling of four doorways, and replacement of rusty bricks. Once again, in 1983, the tiling of the dome's exterior surface was completely replaced due to excessive decay of tiles, and the dome was decorated with black, white, yellow and turquoise tiles in accordance with the main color and form of prior decorations (Figure 11 and 12). 


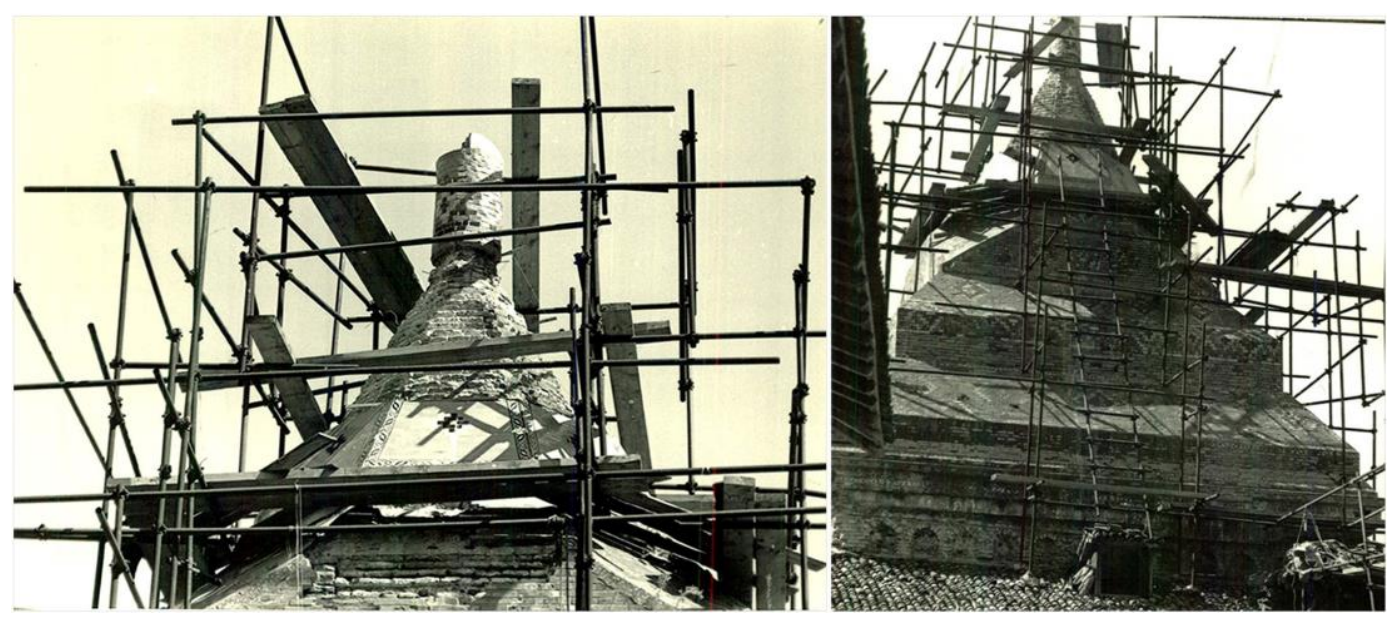

Figure 11. Renovation of the tiles on dome's exterior. (author).

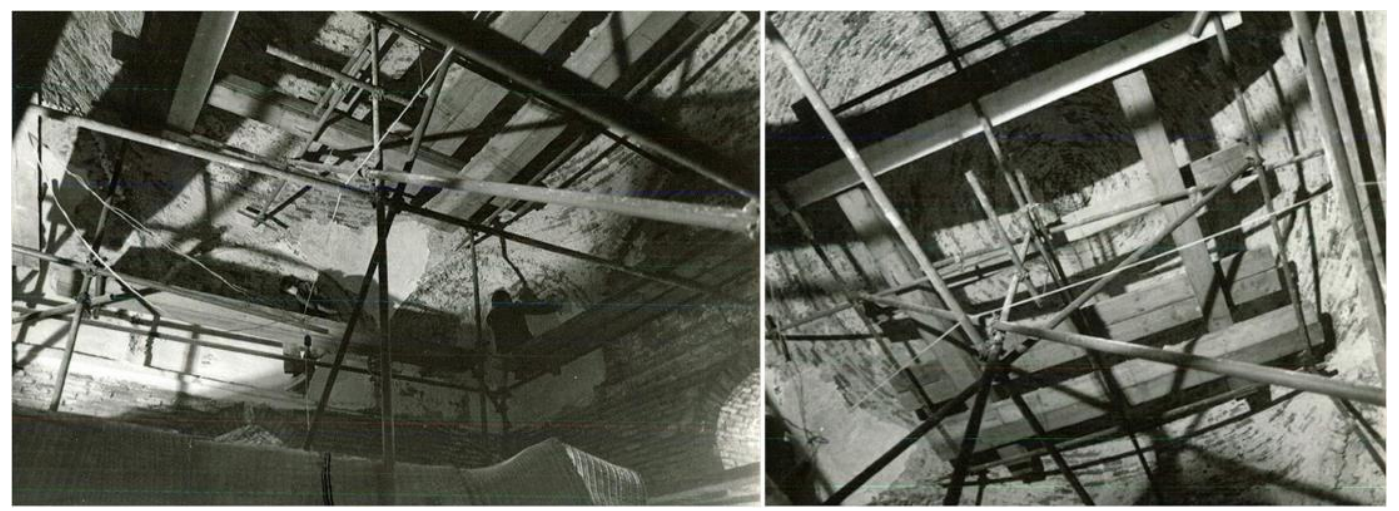

Figure 12. Repair of ceiling plaster under the dome. (author).

During the first period of restoration of the dome in 1986 by the GilanCHTO, due to the exhaustion of about $80 \%$ of the tiles as a result of time lapse and climate conditions, three northern, eastern and southern sides were fundamentally restored. To repair and rebuild the tiles of the dome, white, black, yellow and turquoise tiles were provided according to the size and design of the original tiles, with clay biscuits transferred from Isfahan (Figure 13). This operation was carried out by a contractor. Restoration and reconstruction of the western side was accomplished with a combination of tiles from Isfahan and Mashhad. Moreover, the wooden orisi of the porch, sash windows with decotions, of the northern side was conserved. 


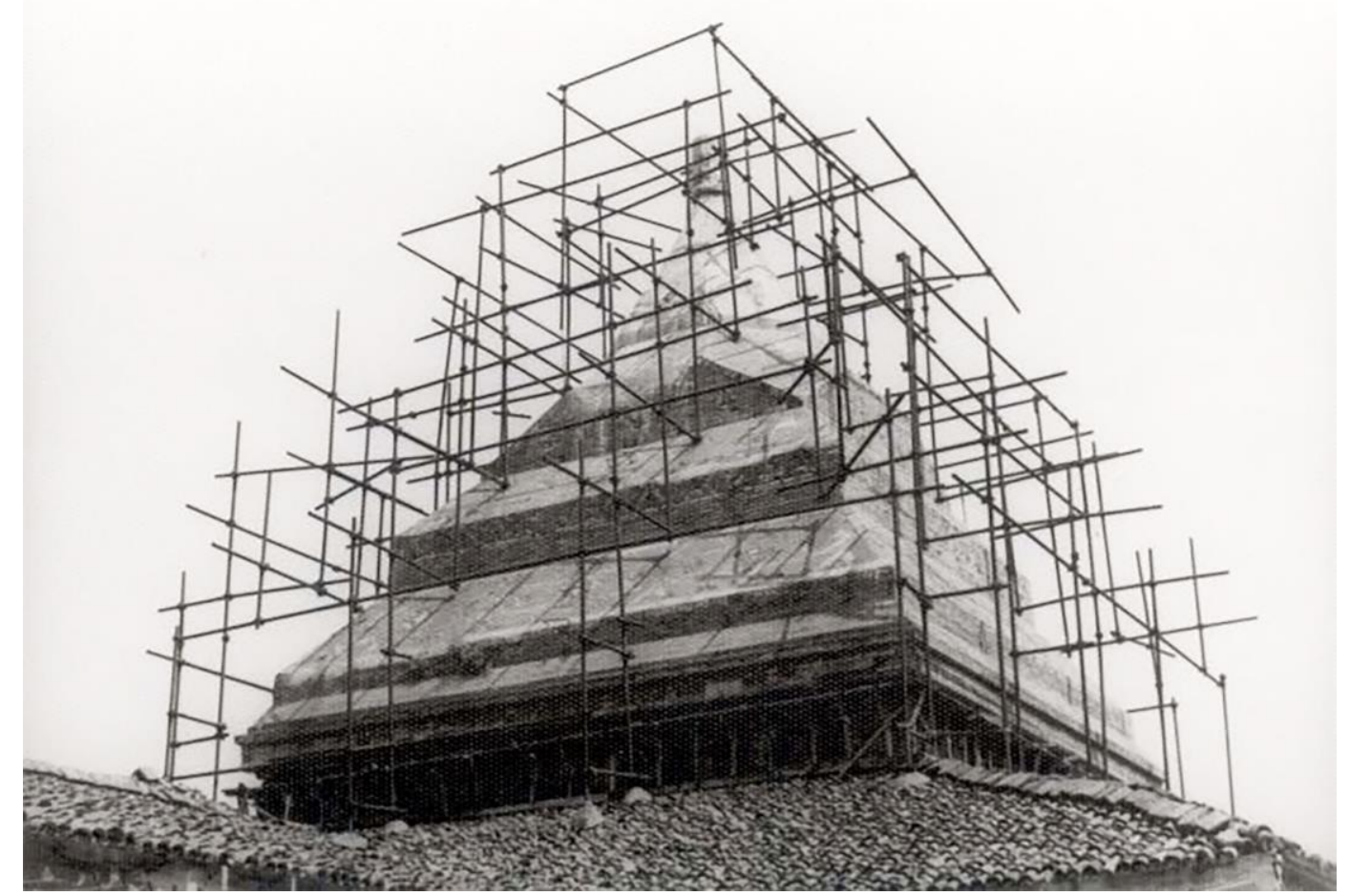

Figure 13. Complete substitution of tiles on dome's exterior. (author).

In the subsequent years (1991-2007), some of the damages to the tomb have also been restored by GilanCHTO ${ }^{69}$. Most of the actions carried out by the GilanCHTO have been on the exterior and courtyard of the tomb, including completion of the paved ramp; construction of an edge for the western side of the ramp and the laying of paths to the streets and alleys; consolidation of the old enclosure walls on the northern side; organization of the restrooms and lighting and arranging garden and landscape. In 1991, about seven thousand broken and worn-out clay tiles of the roof were replaced alongside the rotten wooden structure under the roof and the broken structure of the windows on southern side (Figure 14). Nevertheless, due to heavy rainfall, materials have suffered a loss in quality, the color of the bricks has changed and the wooden structure has become rusty. Handwriting and corrosion of materials have also been created by human factors which requires repair in several places.
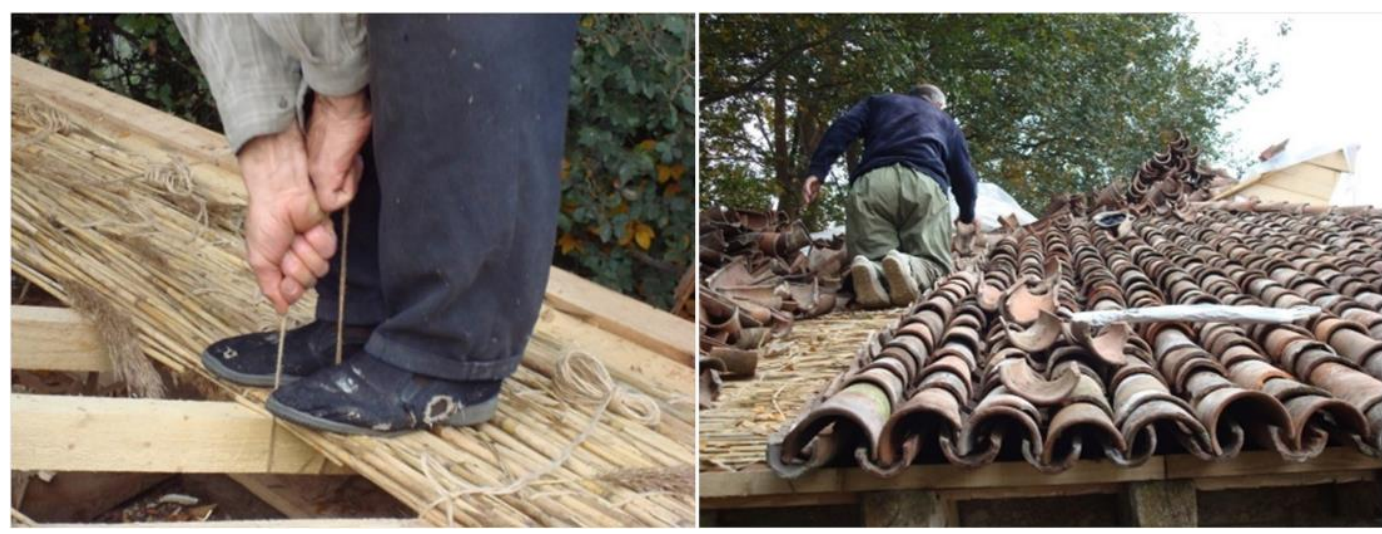

Figure 14. Replacement of the straws and clay roof-covering. (author). 


\subsection{Restoration project by GilanCHTO}

In 2008, research entitled 'Study and Restoration Project of Sheikh Zahed's Tomb' was conducted in two volumes ${ }^{70}$. The study divided the refurbishment operations into three stages. The first stage was to repair and replace the wooden structure of the roof from fir, forest and oak woods that were completely dried to prevent the penetration of insects and the formation of fungus (Figure 15). At the beginning, fourteen rotten beams were cut off from the placement on the brick columns; so that the boards were first removed, then the beams were cut off. The beams were connected temporarily by the wire, and then they were threaded and installed according to their initial position. During the installation of the beams, parts of the damaged wooden eaves overhang were restored.

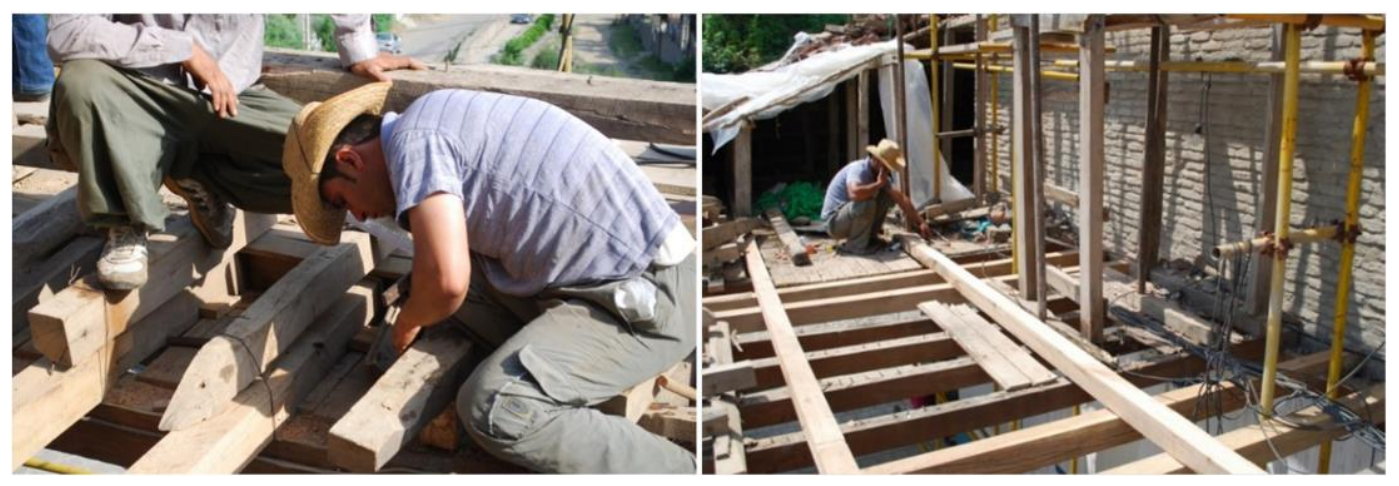

Figure 15. Renovation process of wooden structure of the roof (author).

The second stage was to remove old straws under the clay tiles and to position $60 \mathrm{~m} 2$ shingles for the infrastructure and replace the rusty and broken clay tiles to rearrange clay roof-covering.

In the third stage in 2012, the execution of the tile repair of the tomb's dome was carried out based on the agenda, which included the following steps: the scaffolding and boards were installed at the dome level; Aleppo covers were assembled on ceiling; tiles motifs were modeled and documented; roof bricks and substructures under tiling were strengthened with lime mortar, clay, sand, and rice fiber, according to conducted experiments; and at last, tiles were installed and restored with the required materials (Figure 16 and 17). According to conducted tests, the refinement operations of bricks under the dome tile were carried out with lime mortar, clay, sand and rice fiber. 

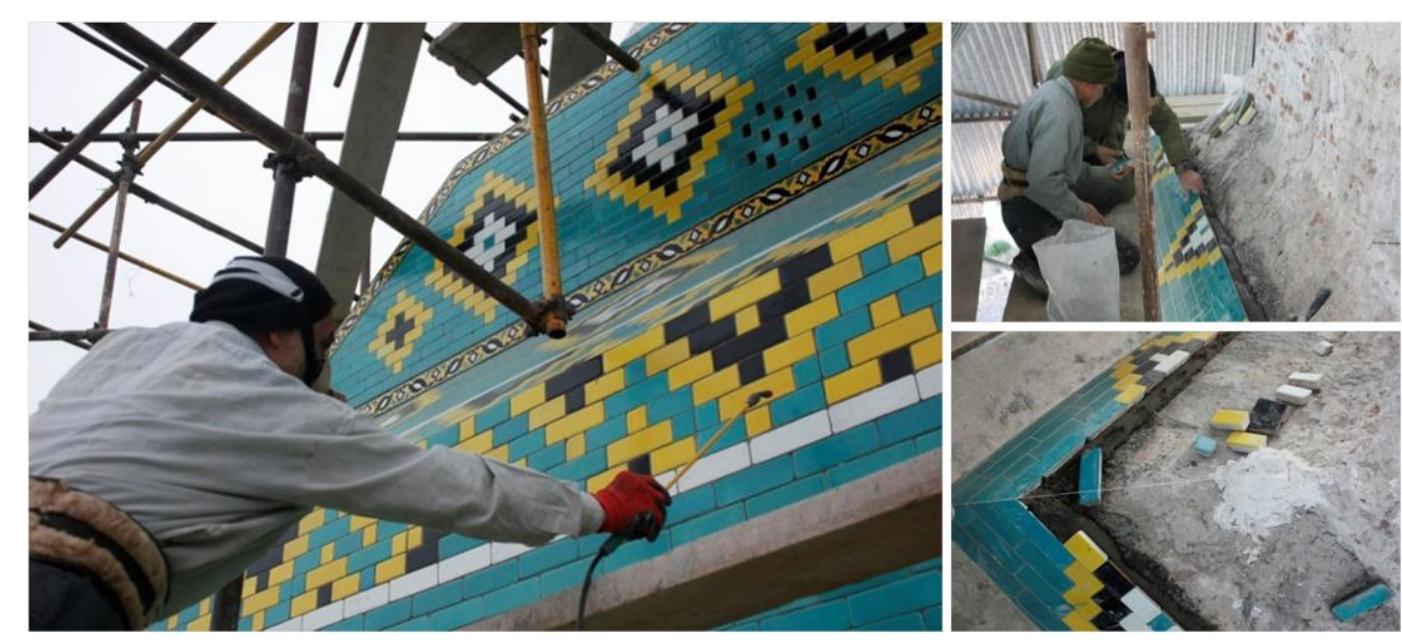

Figure 16. Renovation of dome's tiles. (author).

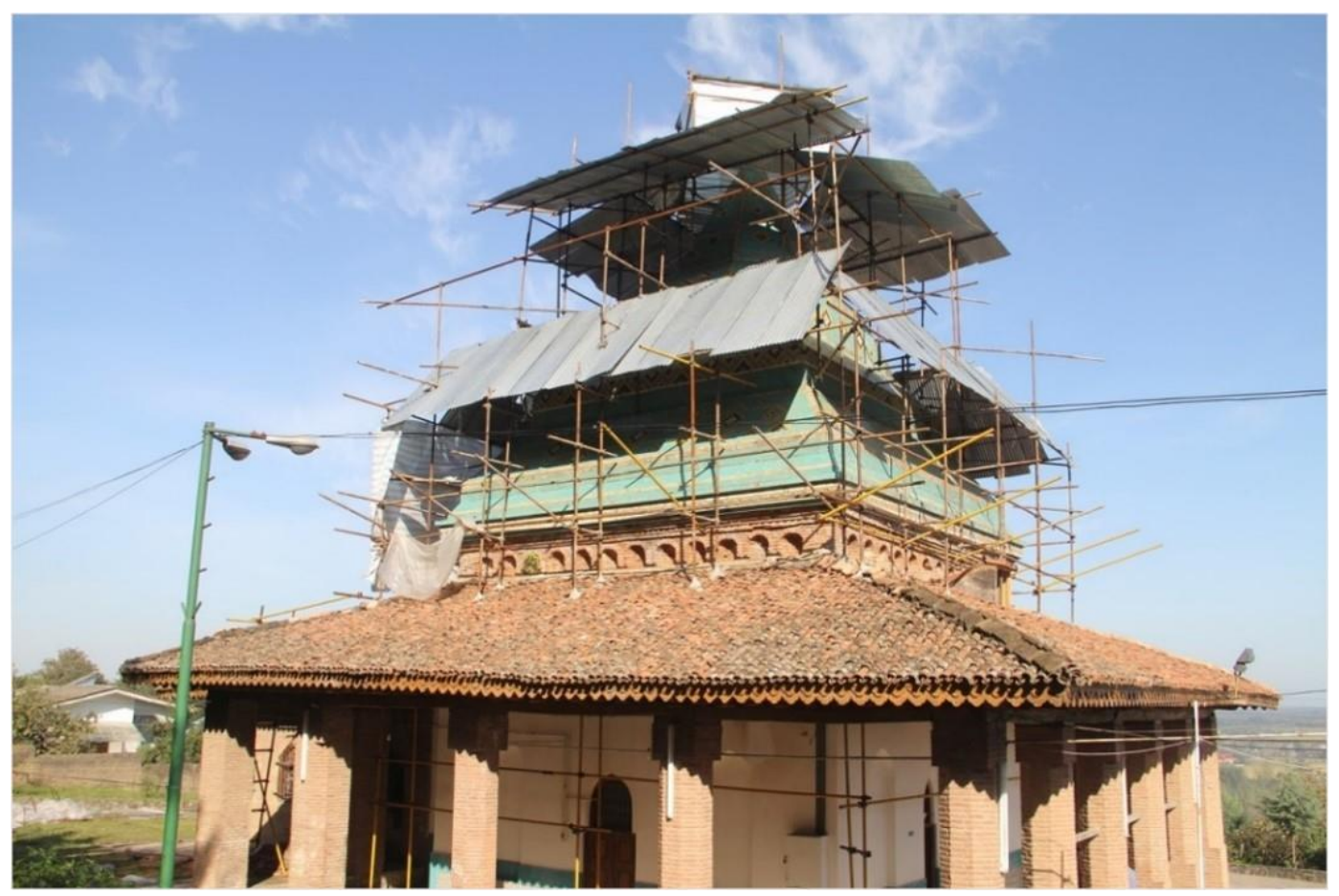

Figure 17. Reassembling dome's tiles. (author).

Ultimately, the last reconstruction project of domes' tiles of the tomb was accomplished in 2012. Moreover, in recent years, a budget has been allocated by GilanCHTO to revitalize the derelict surrounding buildings for the establishment of a local library. These renovation projects, especially the last stage, have made many changes to the tomb that the initial architecture in terms of materials, decorations or structure is difficult to be defined and evaluated. Nonetheless, they facilitated the usage of the tomb, in day and night which led to the increase in the number of visitors in recent decade (Table 2 ). 
Table 2. Assessment of restoration projects. (author).

\begin{tabular}{|c|c|c|}
\hline Stages & Implemented actions & Impacts on contemporary perception/usage \\
\hline $\begin{array}{l}\text { (0) zero stage } \\
(1958-2007)\end{array}$ & $\begin{array}{l}\text { - repair and restore dome } \\
\text { tiles; } \\
\text { - tiling of floors and } \\
\text { doorways; } \\
\text { - restoration of orisi in the } \\
\text { northern porch; } \\
\text { - restoration of the } \\
\text { courtside; } \\
\text { - construction of restrooms } \\
\text { and exterior lighting; } \\
\text { - renovation of brick walls. }\end{array}$ & $\begin{array}{l}\text {-transformation of initial tiles and decorations of the dome; } \\
\text { there is no evidence of the original color, forms and painting } \\
\text { of the dome tiles; } \\
\text { - floors have been transformed from cement to tiles } \\
\text { alongside the walls; there is no evidence of the original form } \\
\text { of wall tiles, wooden windows or the inscription of the } \\
\text { doors; } \\
\text { - streets and alleys as well as a paved ramp has been } \\
\text { established and facilitated free access to the tomb; } \\
\text { - through exterior lighting, tomb have also been visited at } \\
\text { nights; } \\
\text { - new walls prevented destruction of decorations from rain } \\
\text { or earthquakes. }\end{array}$ \\
\hline $\begin{array}{l}\text { (1) first stage } \\
(2008-2010)\end{array}$ & $\begin{array}{l}\text { - renovation of wooden } \\
\text { structures. }\end{array}$ & $\begin{array}{l}\text { - new wooden beams, boards and eaves increased the } \\
\text { stability of the building alongside the appeal of facades. }\end{array}$ \\
\hline $\begin{array}{l}\text { (2) second stage } \\
(2010-2011)\end{array}$ & $\begin{array}{l}\text { - renovation of straws and } \\
\text { clay tiles of the roof. }\end{array}$ & $\begin{array}{l}\text { - new clay tiling promoted the stability, prevented rain and } \\
\text { increased the appeal of clay roof. }\end{array}$ \\
\hline $\begin{array}{l}\text { (3) third stage } \\
\text { (2011-2012) }\end{array}$ & - repair of dome tiles. & $\begin{array}{l}\text { - renovation of the tiles increased the dome attractiveness } \\
\text { and resistance to water, however, the initial material and } \\
\text { decorations of the dome remained unclear. }\end{array}$ \\
\hline
\end{tabular}

\section{Discussion and conclusion}

The paper attempted to assess the historical conflicts and distinctive structural design of Sheikh Zahed Gilani's tomb and whether it could be a proper typology for indigenous religious architecture. Sheikh Zahed Gilani was a mystic in the late Timurid dynasty, whose reputation came across Iran, and his key influence on Sheikh Safi al-Din Ardebili, ancestor of the Shah Ismail, the founder of the Safavid Dynasty, is significant. According to historical books, two tombs are attributed to Sheikh Zahed Gilani, one in the Heliekaran and the other in the Sheikhanebar village, which this study discusses. The examination of the tomb indicates that the direction of the building is 31-degree different from Qibla and it is constructed in four cardinal directions. Moreover, its renowned and unique dome is on the chamber of a person called Seyed Razi and Sheikh Zahed's wooden sepulcher is located in the adjoining room. These cases reduce the possibility of a significant person' burial such as Sheikh Zahed in this place. Nonetheless, in line with the remaining inscriptions, it is believed that Sheikh Zahed Gilani has been buried in this monument.

The dominant structure of the tomb is the pyramid dome which has a geometrical design of eight levels, transforming consistently from vertical to oblique surfaces. The survey illustrated that designers utilized a 45-degree geometry to develop the dome and together with golden ratios, have located the pillar around the monument. This precise geometry is also combined with wooden, brick and tile decorations retrieved from nature. These 
features have led the dome to be a respectable sample for an indigenous and rain-fed climate of the region as a result of the easy flow of rain.

With its architecture aesthetics, the tomb has attracted many cultural tourists, manifesting the cultural/religious identity of the past. Regarding cultural potentials, GilanCHTO has deliberated several renovation projects since the current situation of the tomb necessitates urgent conservation. Several cases have been considered in this project: (1) coordination of the architecture, materials and facade of built units with the cultural-historical context of the complex; (2) the approval of GilanCHTO for any construction activities within the scope of this privacy; (3) and the confirmation of GilanCHTO for any developmental measures, telecommunication towers, cutting down trees, removing or redirecting surface water in order to maintain the natural landscape and environmental values. On the whole, this study has limited to one tomb in northern Iran. Further research is required to examine more shrines, mosques, and mausoleums and specifically Sheikh Zahed Gilan's tomb to conceptualize a typology for religious monuments for contemporary religious architectural projects.

\section{Endnotes}

1. Reza Shateriyan, Analysis of Architecture of Mosques in Iran (Tehran: Nopardazan, 2011), 116.

2. Nasran Kazemzaki and Amir Hashempour Mafi, 'Investigating the Past Physical Identity of Sheikh Zahed Tomb in Lahijan' (paper presented at the Third International Conference \& Forth National Conference on Civil Engineering, Architecture and Urban Design, Tabriz Islamic Art University, Iran, September 5-7, 2018).

3. Roghayeh Mansouri Parsa, 'Investigating Pattern and Geometry of the Dome in the Caspian Sea, Case Study: Sheikh Zahed Gilani Tomb in Lahijan' (paper presented ar the First National Conference of Ideas and New Technologies in Architecture, Association of Architects of East Azarbaijan, Iran, March 11, 2012).

4. Mohammad Mehdi Raeis Samiei, Mojgan Khakpour, and Niloufar Dadashzadeh, 'The Study of Sheikh Zahed Gilani's Mausoleum Based on Features of Vernacular and Traditional Architecture' (paper presented at the First International Congress of New Horizons in Architecture and Urbanism, HIAP, Iran, January 7-8, 2014).

5. Masoud Soufinezhad Siviri, 'Lahijan, Bride of Iranian Cities', Padang, 20 (2006), 37-38.

6. Manouchehr Setoudeh, From Astara to Estarabad (Tehran: Society for the Appreciation of National Works and Dignitaries, 1995), 69.

7. Alevier/Alevism is a syncretic, dissident, and local Islamic practice, whose devotees pursue the mystical didactics of Imam Ali.

8. Karkiya/Kia dynasty (1370 to 1592), contending Sasanian ancestry, was a Zaydi Shia dynasty which ruled over Bia pish (eastern Gilan). 
9. An Imamzadeh is a shrine/mausoleum/tomb of a descendant of a Shi'i Imam.

10. Minoo Khakpour, 'Typology of the blessed monasteries of Lahijan', Journal of Studies on Iranian-Islamic City, 13 (2013), 84.

11. Setoudeh, Astara to Estarabad, 75-76.

12. Reza Jafari Nosratabad and Khosro Kamali Sarvestani, 'Sheikh Zahed Gilani's Themes in the Book of Safvat al-Safa Ibn Bazzaz and its comparison to other sources' (paper presented at the National Conference on the Third Millennium and Humanities, Center for Advanced Training, Iran, June, 2015).

13. Mojtaba Pour Ahmadi, 'Geometry in the Dome of Sheikh-Zahed-e-Guilani Shrine: A Model for Designing Domes in the Southern Coasts of the Caspian Sea', Honar-Ha-Ye-Ziba; Memari-VaSharsazi, 43 (2010), 84.

14. Mohammad Ali Gilak, Sheikh Zahed Gilani (Tehran, 1966), 23.

15. Saeed Nafisi, Sheikh Zahed Gilani (Tehran: Farhang Publishers, 1928), 7-8.

16. Mohammad Karim Yusef Jamali and Abbas Panahi, 'Mutual Relationships between Sheikh Zahed Gilan and Sheikh Safi al-Din Ardebili on each other', Journal of History, 9 (2009), 141.

17. He was the Kurdish and Sunni Muslim eponym of the Safavid dynasty; He transformed the Sufi order of Zahediyeh into the "Safaviyya" order; Jafari Nosratabad and Kamali Sarvestani, 'Sheikh Zahed Gilani's Themes'.

18. The Safavid dynasty (1501-1736), one of the most notable dominant dynasties of Iran, is regarded the initiation of modern Iranian history.

19. Mohammad Shoormeij, 'Political Approach of Sheikh Zahed Gilani and Sheikh Safi al-Din Ardebili from Perspective of Historical Texts', Islamic Studies: History and Culture, 87 (2011), 89.

20. Jafari Nosratabad and Kamali Sarvestani, 'Sheikh Zahed Gilani’s Themes’.

21. Members of the Timurid dynasty were strongly influenced by the Persian culture and established two significant empires in history; one of which was the Timurid Empire (1370-1507) based in Persia and Central Asia.

22. Pour Ahmadi, 'Geometry in the Dome', 84.

23. Raeis Samiei et al., 'Sheikh Zahed Gilani’s Mausoleum'.

24. Vahid Ghobadian, Climatic Analysis of the Traditional Iranian Buildings (Tehran: University of Theran Press, 2011), 210.

25. Raeis Samiei et al., 'Sheikh Zahed Gilani’s Mausoleum'.

26. Ghobadian, Climatic Analysis of Buildings, 210.

27. Mansoureh Tahbaz and Shahrbanoo Djalilian, Architectural Design Principal Compatible with 
Climatic Conditions of Iran with focus on Mosque Design (Tehran: Shahid Beheshti University Press, 2011), 34.

28. Hossein Zomarshidi, Iraniani Architecture: Building Construction with Tradtional Materials (Tehran: Zomorrod Press, 2010), 14.

29. Ghobadian, Climatic Analysis of Buildings, 42.

30. Setoudeh, Astara to Estarabad, 152-153.

31. Nafisi, Sheikh Zahed Gilani, 26.

32. Timur (1336-1405), best known as Amir Timur or Tamerlane, was a Turco-Mongol Persianate conqueror who founded the Timurid Empire in and around modern-day Iran and Central Asia, becoming the first ruler of the Timurid dynasty.

33. Setoudeh, Astara to Estarabad, 152-153.

34. Mahmoodi and Mohammad Alyan, 'Five Principles of Persian Architecture'.

35. Nima Valibeig, Sanaz Rahravi Poodeh, and Afrooz Rahimi Ariaei, 'Structural and Geometric Analysis of Discontinuous Double-Shell Persian Domes in Isfahan and Nain Dome-Building Schools', International Journal of Architectural Heritage: Conservation, Analysis, and Restoration, (2017), 3, doi:10.1080/15583058.2017.1325540

36 Maryam Ashkan, Yahaya Ahmad, and Ezrin Arbi, 'Pointed Dome Architecture in the Middle East and Central Asia: Evolution, Definitions of Morphology, and Typologies', International Journal of Architectural Heritage: Conservation, Analysis, and Restoration, 1 (2012), 46-61. doi:10.1080/15583058.2010.501400

37. Hossein Zomarshidi, Dome and Vaulted Elements of Iran (Tehran: Nashr-e Zaman, 2010), 346.

38. Shateriyan, Mosques in Iran, 252.

39. Rabino, Le Guilan, 339.

40. Mojtaba Pour Ahmadi, 'A Geometrical Analysis of the Mausoleum of Sheikh Zahed-e Gilani', Nexus Netw Journal, 2 (2012), 393. doi:10.1007/s00004-012-0114-8

41. Setoudeh, Astara to Estarabad, 148-149.

42. Pour Ahmadi, Geometry in the Dome, 90.

43. Raeis Samiei et al., 'Sheikh Zahed Gilani’s Mausoleum'.

44. GilanCHTO, Restoration Report of Sheikh Zahed Gilani's Tomb (Rasht: Cultural Heritage and Tourism Organization of Gilan Province, 2011).

45. The Qajar dynasty was an Iranian royal dynasty of Turkic origin, specifically from the Qajar tribe, ruling over Iran from 1789 to 1925.

46. Mansouri Parsa, 'Pattern and Geometry of the Dome'. 
47. Shateriyan, Mosques in Iran, 128.

48. Kazemzaki and Hashempour Mafi, 'Past Physical Identity of Sheikh Zahed Tomb'.

49. A tile style with regular shapes and dimensions based on the tastes of the master and the characteristics of the work location, mainly in the shapes of squares, rectangles, hexagons or etc. in the usual sizes of $15 \times 15$ and $20 \times 20 \mathrm{~cm}$ and for minaret and dome in the sizes of $15 \times 7,5$ or 20 $\times 10 \mathrm{~cm}$, which are made in the clay form.

50. Mahmoodi and Mohammad Alyan, 'Five Principles of Persian Architecture'.

51. A combination of tiling with brickwork, made by building and placing tiles with very small dimensions.

52. GilanCHTO, Restoration Report.

53. Mahmoodi and Mohammad Alyan, 'Five Principles of Persian Architecture'; Raeis Samiei et al., 'Sheikh Zahed Gilani's Mausoleum'.

54. GilanCHTO, Restoration Report.

55. Rabino, Le Guilan, 339; Nafisi, Sheikh Zahed Gilani, 26.

56. Setoudeh, Astara to Estarabad, 150.

57. Setoudeh, Astara to Estarabad, 151.

58. Shateriyan, Mosques in Iran, 363.

59. Khakpour, 'Lahijan’s Monasteries', 82.

60. Zomarshidi, Iraniani Architecture, 177.

61. Ghobadian, Climatic Analysis of Buildings, 62.

62. Tahbaz and Djalilian, Architectural Design with Climatic Conditions, 34.

63. Tahbaz and Djalilian, Architectural Design with Climatic Conditions, 42

64. Zomarshidi, Iraniani Architecture, 368.

65. Ghobadian, Climatic Analysis of Buildings, 53.

66. Maryam Kamali, 'Sufism, Shia and Sunni coexistence in the tomb of Bayazid Bastami and Sheikh Zahed Gilani', (2014), Retrieved from website: fa.iranianmedievalhistory.com (Accessed on 2016/01/04).

67. GilanCHTO, Restoration Report.

68. INOAHP, Restoration of Sheikh Zahed Gilani's Tomb (Tehran: Iran National Organization of Archeological Heritage's Protection, 1984). 
69. Khakpour, 'Lahijan's Monasteries', 87.

70. GilanCHTO, Restoration Report. 